\title{
Low detectability of alien reptiles can lead to biosecurity management failure: a case study from Christmas Island (Australia)
}

\author{
Pablo García-Díaz ${ }^{1,2}$, Joshua V. Ross ${ }^{3}$, Miquel Vall-llosera', Phillip Cassey' \\ I School of Biological Sciences, The University of Adelaide, North Terrace SA 5005, Australia 2 Manaaki Whe- \\ nua - Landcare Research, Lincoln 7608, New Zealand 3 School of Mathematical Sciences, NHMRC Centre of \\ Research Excellence in Policy Relevant Infectious Diseases Simulation and Mathematical Modelling (PRISM2), \\ and ARC Centre of Excellence for Mathematical and Statistical Frontiers (ACEMS), The University of Adelai- \\ de, North Terrace SA 5005, Australia \\ Corresponding author: Pablo García-Díaz (garcia-diazp@landcareresearch.co.nz) \\ Academic editor: Sven Bacher | Received 1 November 2018 | Accepted 27 March 2019 | Published 7 May 2019 \\ Citation: García-Díaz P, Ross JV, Vall-llosera M, Cassey P (2019) Low detectability of alien reptiles can lead to biosecurity \\ management failure: a case study from Christmas Island (Australia). NeoBiota 45: 75-92. https://doi.org/10.3897/ \\ neobiota.45.31009
}

\begin{abstract}
When we assume that contemporary management actions will be effective against the global rise of emerging alien species, we can develop management complacency, which leads to potentially disastrous outcomes for native biodiversity. Here, we propose the use of the probability of detection as a metric to assess the feasibility of management actions for alien species. We explore how detectability can influence the management of alien reptiles, a group of emergent alien vertebrates globally. We use a Rapid Biological Assessment method (time-limited transects) to estimate the probability of detection for alien reptiles present on Christmas Island (Australia). Across the five species studied, we found low probabilities of detection and poor explanatory capacity of the individual covariates included in our models. These findings indicate that management options to deal with alien reptiles are limited due to the potential high cost and low efficacy associated with low probabilities of detection. Strict preventive strategies, firmly espousing the principles of adaptiveness and precautionary policies, combined with early detection and biosecurity response activities are needed to address the emergence of alien reptiles. Our research was focussed on alien reptiles on islands, but the rise of new pools of alien species from all taxonomic realms across the world suggests that our conclusions may be applicable more generally. Further research is called for to explore the applicability of our conclusions and recommendations to other taxonomic groups and regions of the world.
\end{abstract}

Copyright Pablo García-Díaz et al. This is an open access article distributed under the terms of the Creative Commons Attribution License (CC BY 4.0), which permits unrestricted use, distribution, and reproduction in any medium, provided the original author and source are credited. 


\section{Keywords}

Anticipatory policy-making; Christmas Island; preventive decision-making; probability of detection; Rapid Biological Assessment; uncertainty

\section{Introduction}

The global emergence of a new pool of alien species may render existing management actions, ranging from rapid incursion response to the eradication of self-sustaining populations, ineffective (Hulme 2015; Seebens et al. 2018). For example, while the increasingly successful program of invasive alien rodent eradications is well documented (Howald et al. 2007), large-scale attempts to eradicate invasive alien reptiles, a group of emergent alien vertebrates, have failed (Kraus 2009; García-Díaz et al. 2017a). Additionally, the allocation of resources along the management continuum (from prevention to eradication) is complicated by the uncertainties surrounding the costs and benefits of emerging alien species, and the realised efficacy of practical activities (McIntosh et al. 2009; Rout et al. 2014). Assuming that management actions, which have been demonstrated and validated on historical alien species, will work as effectively with novel pools of alien species is risky and can lead to poor management outcomes (or complete failure) in the face of increasing introductions of new alien species (Gregory et al. 2014; Early et al. 2016).

Successful management of alien species depends on the capacity to anticipate the specific transport pathways, which move alien species, and on adapting management actions to address the associated novel risk. While substantial research effort has been invested in understanding the dynamics of changing pathways (Hulme 2015; Seebens et al. 2018), less has focussed on assessing the efficacy and effectiveness of existing management actions. The probability of detection (or capture) of an individual, provides a simple quantitative measure of the likely effort needed to manage new alien species. In turn, the capacity to assess management efforts needed to contend with new alien species provides an indicator of the estimated efficacy of candidate management actions. Critical alien species management actions such as: (i) quarantine; (ii) early detection and either rapid containment, control, or suppression of recent introductions; and (iii) eradication, cannot proceed unless the individuals of an alien species can be reliably detected (Christy et al. 2010; Holden et al. 2016; García-Díaz et al. 2017b). To complicate matters further, during quarantine and early detection activities the presence of a new alien species and the identity of such are not necessarily known a priori. This undermines the possibility of designing and planning speciesspecific surveillance approaches and implies a need for a multi-purpose surveying methodology, which is reliable across a broad range of taxa.

Rapid Biological Assessments (RBAs) are a widely used tool for conducting biodiversity inventories and monitoring, balancing reliability in sampling biological communities with time and resource constraints to conduct the surveys (Sutherland 2006; Larsen 2016). These features make RBAs a prime candidate for conducting standardised surveys in a timely and cost-effective manner, fitting well the need for 
rapid detection of new alien species to trigger management actions. However, the reliability of standardised RBAs to suit the needs of alien species management activities needs to be evaluated before they are adopted. In particular, it is essential to establish the capacity to detect the presence of alien species during RBAs (Catenazzi et al. 2016; García-Díaz et al. 2017a).

Reptiles are a notable group of emergent alien species responsible for serious environmental impacts in recipient regions worldwide, especially on islands (Rodda et al. 1999; Christy et al. 2010; Powell 2011; Smith et al. 2012a; Kraus 2015). Alien reptiles are frequently transported both unintentionally (i.e., as stowaways) and intentionally (e.g., through the pet trade), and the accelerating volume of global traffic has increased their opportunities for introduction into new regions (Kraus 2009; Powell 2011; Helmus et al. 2014; Capinha et al. 2017; Moser et al. 2018). In this work, we use a candidate survey methodology (RBAs) to detect alien reptiles. Given the key importance of detecting alien individuals, we explore how detectability can lead to challenges to the effective management of alien reptiles. Taking our findings into account, we suggest policy directions for the effective management of new and emergent alien species.

We investigated a standardised RBA using the case study of the detection of alien reptiles on Christmas Island (Fig. 1). The introduction of five species of invasive alien reptiles on Christmas Island provides the opportunity to investigate how the probabilities of detection could influence the feasibility of management actions for four of the most commonly transported and introduced families of alien reptiles worldwide, including on islands (Kraus 2009; Helmus et al. 2014; Capinha et al. 2017). To date, Christmas Island has been invaded by two species of geckos (family Gekkonidae; common house gecko, Hemidactylus frenatus, and stump-toed gecko, Gehyra mutilata), a skink (Scincidae: grass skink, Lygosoma bowringii), and two snakes (family Typhlopidae: flowerpot snake, Indotyphlops braminus: and family Colubridae: wolf snake, Lycodon capucinus).

\section{Methods}

\section{Study area and survey sites}

Christmas Island is an Australian oceanic territory located in the Indian Ocean, $10^{\circ}$ $30^{\prime} \mathrm{S} 105^{\circ} 40^{\prime} \mathrm{E}$ (Fig. 2). The island has an area of $135 \mathrm{~km}^{2}$, of which approximately $63 \%$ is a National Park. The island has a tropical climate, with rainforest covering most of it, although phosphorus mining has transformed some areas (Fig. 1). The island's landscape and habitat features are described in greater detail elsewhere (Claussen 2005; Smith et al. 2012b). The island's native biota has suffered a catastrophic extinction crisis since its human colonisation in the 1890 s, with most of its terrestrial vertebrate species, except birds, extinct as a consequence of the impacts caused by humans and alien species (Wyatt et al. 2008; Smith et al. 2012b). 

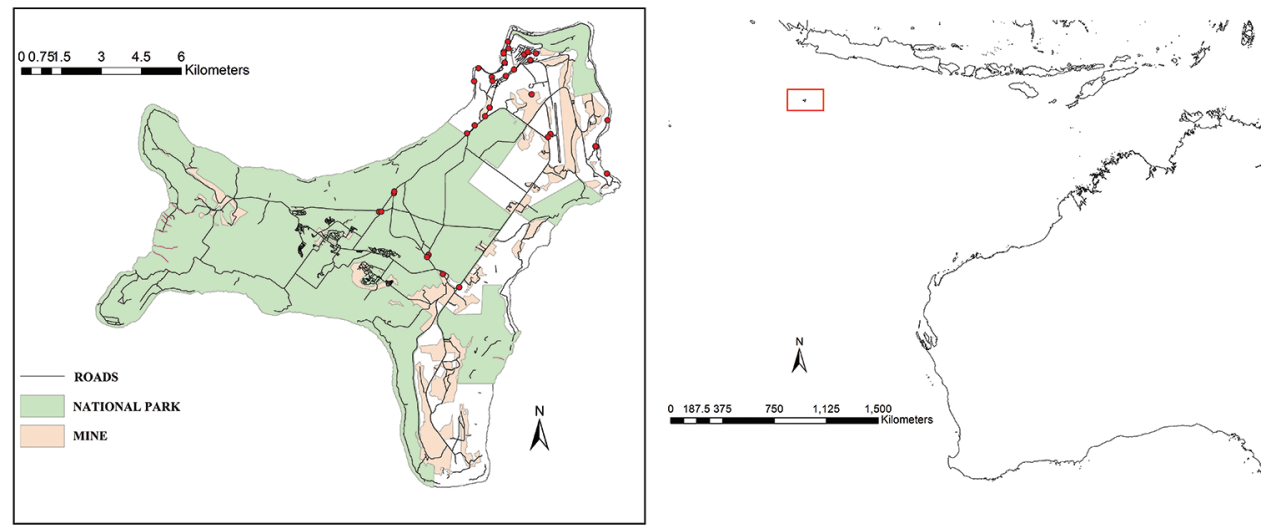

Figure I. Major land uses on Christmas Island and the geographical distribution of the 34 survey sites (red dots), left panel, and geographical location of Christmas Island (box in right panel map) illustrating its remoteness and position with respect to Australia and Indonesia.

We identified 34 survey sites (Fig. 1) through expert consultation with representatives of the Christmas Island National Park and Natural Resource Management Board (S. Flakus, B. Tiernan, D. Maple, M. Misso) and the Australian Government Department of Agriculture and Water Resources (J. Matthews). These sites are representative of the current distribution of all five alien reptiles, and include potential entry points for new alien reptiles, such as the port and the airport. We concentrated our survey efforts on the western part of Christmas Island because all five species of alien reptiles occur mostly around the more disturbed and human-altered locations (see distribution maps in Smith et al. 2012b). These 34 survey sites encompass the variety of environmental conditions and different alien reptile abundances (Table 1 and see data available at https://figshare.com/s/e85ac13693bc6272437f).

\section{Standardised Rapid Biological Assessment: a time-limited approach}

We surveyed for alien reptiles during the dry season, $8^{\text {th }}$ July to $7^{\text {th }}$ August 2015, to minimise disturbances caused by the inclement weather conditions of the wet season. Each of the survey sites was surveyed using the time-limited transect approach; a standardised RBA for reptiles and amphibians (Catenazzi et al. 2016). In each of the survey sites, we intensively searched for alien reptiles during 10 minutes along a linear transect (mean \pm standard error: $182.71 \pm 72.59 \mathrm{~m}$; range: $60-384 \mathrm{~m}$ ). Our models indicated that the wide range of distances surveyed did not influence the results of the surveys (Table 1). We intensively searched for alien reptiles under rocks or other fallen structures (e.g., logs), and in the vegetation, during both day and night surveys (using a Led Lenser H14R.2 head torch during night surveys). Each site was surveyed on six occasions, three after sunset (during night time 18:20-20:40), and three after sunrise 
Table I. Goodness of fit (Bayesian $p$-values), summary statistics of the covariates (before standardisation; mean \pm standard deviation, and range), and posterior coefficient estimates (mean \pm standard error, and $95 \%$ Credible Intervals) of the abundance-detection models for five species of alien reptiles on Christmas Island.

\begin{tabular}{|c|c|c|c|c|c|c|}
\hline & $\begin{array}{c}\text { Covariate summary } \\
\text { statistics (original } \\
\text { units) }\end{array}$ & $\begin{array}{c}\begin{array}{c}\text { Common } \\
\text { house gecko }\end{array} \\
\text { (Hemidactylus } \\
\text { frenatus) } \\
\end{array}$ & $\begin{array}{c}\text { Stump-toed } \\
\text { gecko (Gehyra } \\
\text { mutilata) }\end{array}$ & $\begin{array}{l}\text { Grass skink } \\
\text { (Lygosoma } \\
\text { bowringii) }\end{array}$ & $\begin{array}{c}\text { Flowerpot snake } \\
\text { (Indotyphlops } \\
\text { braminus) }\end{array}$ & $\begin{array}{l}\text { Wolf snake } \\
\text { (Lycodon } \\
\text { capucinus) }\end{array}$ \\
\hline Bayesian p-value & & 0.51 & 0.49 & 0.44 & 0.29 & 0.31 \\
\hline $\begin{array}{l}\text { Estimated mean abundance } \\
\text { (across survey sites) }\end{array}$ & & \begin{tabular}{|c|}
$67.27 \pm 27.15$ \\
$(34.68,152.85)$
\end{tabular} & $\begin{array}{l}24.19 \pm 78.86 \\
(1.50,265.14)\end{array}$ & $\begin{array}{l}1.83 \pm 2.25 \\
(0.77,6.94)\end{array}$ & $\begin{array}{l}0.62 \pm 0.24 \\
(0.35,1.24)\end{array}$ & $\begin{array}{l}5.43 \pm 10.93 \\
(0.53,32.18)\end{array}$ \\
\hline \multicolumn{7}{|c|}{ Probability of individual detection (across survey sites) } \\
\hline Day & & $\begin{array}{l}0.007 \pm 0.008 \\
(0.002,0.03)\end{array}$ & $\begin{array}{c}0.001 \pm 0.007 \\
(0.00,0.001)\end{array}$ & $\begin{array}{l}0.22 \pm 0.15 \\
(0.03,0.60)\end{array}$ & $\begin{array}{l}0.15 \pm 0.13 \\
(0.05,0.53)\end{array}$ & $\begin{array}{l}0.02 \pm 0.04 \\
(0.00,0.15)\end{array}$ \\
\hline Night & & $\begin{array}{l}0.08 \pm 0.05 \\
(0.02,0.21)\end{array}$ & $\begin{array}{c}0.11 \pm 0.11 \\
(0.005,0.42)\end{array}$ & $\begin{array}{l}0.009 \pm 0.02 \\
(0.001,0.06)\end{array}$ & $\begin{array}{l}0.02 \pm 0.04 \\
(0.00,0.53)\end{array}$ & $\begin{array}{c}0.03 \pm 0.04 \\
(0.003,0.12)\end{array}$ \\
\hline \multicolumn{7}{|c|}{ Probability of individual detection: logit model } \\
\hline Intercept (day) & & $\begin{array}{l}-5.31 \pm 0.50 \\
(-6.46,-4.50)\end{array}$ & $\begin{array}{c}-8.61 \pm 6.12 \\
(-25.47,-4.83) \\
\end{array}$ & $\begin{array}{l}-1.30 \pm 0.88 \\
(-3.30,0.16) \\
\end{array}$ & $\begin{array}{l}-1.67 \pm 0.65 \\
(-2.69,-0.40) \\
\end{array}$ & $\begin{array}{l}-4.01 \pm 1.51 \\
(-7.94,1.92) \\
\end{array}$ \\
\hline Intercept (night) & & $\begin{array}{c}-2.06 \pm 0.5 \\
(-3.25,-1.18)\end{array}$ & $\begin{array}{l}-2.21 \pm 1.26 \\
(-5.35,-0.43)\end{array}$ & $\begin{array}{l}-4.70 \pm 1.22 \\
(-7.69,-2.89)\end{array}$ & $\begin{array}{l}-1.42 \pm 0.59 \\
(-2.69,0.40)\end{array}$ & $\begin{array}{l}-4.32 \pm 1.51 \\
(-8.19,-2.19)\end{array}$ \\
\hline $\begin{array}{l}\text { Ground temperature } \\
\text { (standardised) }\end{array}$ & \begin{tabular}{|c|} 
Degree Celsius 26.75 \pm \\
$3.61(20.0-48.0)$ \\
\end{tabular} & $\begin{array}{l}0.10 \pm 0.10 \\
(-0.11,0.29)\end{array}$ & $\begin{array}{l}-0.11 \pm 0.56 \\
(-1.64,0.70)\end{array}$ & $\begin{array}{l}-0.15 \pm 0.19 \\
(-0.55,0.19)\end{array}$ & $\begin{array}{l}-0.08 \pm 0.34 \\
(-0.92,0.47)\end{array}$ & $\begin{array}{c}0.12 \pm 0.34 \\
(-0.56,0.79)\end{array}$ \\
\hline $\begin{array}{l}\text { Temperature } 10 \mathrm{~cm} \text { above } \\
\text { ground (standardised) }\end{array}$ & \begin{tabular}{|c|} 
Degree Celsius $26.40 \pm$ \\
$2.47(21.0-33.5)$
\end{tabular} & $\begin{array}{c}0.10 \pm 0.14 \\
(-0.19,0.37)\end{array}$ & $\begin{array}{l}-0.09 \pm 0.16 \\
(-1.29,0.61)\end{array}$ & $\begin{array}{l}-0.29 \pm 0.37 \\
(-1.18,0.22)\end{array}$ & $\begin{array}{l}0.05 \pm 0.40 \\
(-0.75,0.91)\end{array}$ & $\begin{array}{c}0.02 \pm 0.44 \\
(-0.88,0.96)\end{array}$ \\
\hline $\begin{array}{l}\text { Temperature } 10 \mathrm{~cm} \\
\text { underground (standardised) }\end{array}$ & \begin{tabular}{|c|} 
Degree Celsius $26.40 \pm$ \\
$2.41(21.6-33.8)$ \\
\end{tabular} & $\begin{array}{l}-0.11 \pm 0.09 \\
(-0.29,0.06)\end{array}$ & $\begin{array}{c}0.12 \pm 0.28 \\
(-0.34,0.81)\end{array}$ & $\begin{array}{c}0.07 \pm 0.33 \\
(-0.64,0.71)\end{array}$ & $\begin{array}{c}0.35 \pm 0.42 \\
(-0.26,1.37) \\
\end{array}$ & $\begin{array}{c}0.43 \pm 0.41 \\
(-0.18,1.39)\end{array}$ \\
\hline $\begin{array}{l}\text { Temperature } 120 \mathrm{~cm} \text { above } \\
\text { ground (standardised) }\end{array}$ & \begin{tabular}{|c|} 
Degree Celsius $26.25 \pm$ \\
$2.29(21.40-33.80)$
\end{tabular} & $\begin{array}{l}0.52 \pm 0.16 \\
(0.22,0.84)\end{array}$ & $\begin{array}{c}0.13 \pm 0.47 \\
(-0.54,1.39)\end{array}$ & $\begin{array}{c}0.50 \pm 0.52 \\
(-0.25,1.73)\end{array}$ & $\begin{array}{c}0.02 \pm 0.44 \\
(-0.96 .0 .89)\end{array}$ & $\begin{array}{l}-0.26 \pm 0.54 \\
(-1.62,0.49)\end{array}$ \\
\hline \multicolumn{7}{|c|}{ Abundance: Negative Binomial regression } \\
\hline $\begin{array}{l}\text { Distance to port } \\
\text { (standardised) }\end{array}$ & $\begin{array}{c}\text { Metres } 1937.0 \pm \\
2876.45(138.0, \\
8575.0)\end{array}$ & $\begin{array}{c}0.01 \pm 0.21 \\
(-0.39,0.43)\end{array}$ & $\begin{array}{c}0.26 \pm 0.32 \\
(-0.36,0.98)\end{array}$ & $\begin{array}{c}0.15 \pm 0.32 \\
(-0.48,0.79)\end{array}$ & $\begin{array}{c}0.01 \pm 0.15 \\
(-0.29,0.35)\end{array}$ & $\begin{array}{l}-0.04 \pm 0.27 \\
(-0.61,0.44)\end{array}$ \\
\hline Cover of trees & $\begin{array}{c}\text { Scale } 2.00 \pm 1.82 \\
(0-5.00)\end{array}$ & $\begin{array}{c}0.12 \pm 0.15 \\
(-0.17,0.43)\end{array}$ & $\begin{array}{c}0.07 \pm 0.27 \\
(-0.40,0.70)\end{array}$ & $\begin{array}{l}-0.25 \pm 0.26 \\
(-0.78,0.23) \\
\end{array}$ & $\begin{array}{c}0.01 \pm 0.12 \\
(-0.21,0.27)\end{array}$ & $\begin{array}{l}-0.27 \pm 0.26 \\
(-0.91,0.10) \\
\end{array}$ \\
\hline Cover of bush & $\begin{array}{l}\text { Scale } 2.00 \pm 1.63 \\
(0.00-5.00)\end{array}$ & $\begin{array}{l}-0.11 \pm 0.18 \\
(-0.47,0.47)\end{array}$ & $\begin{array}{l}-0.13 \pm 0.30 \\
(-0.79,0.62)\end{array}$ & $\begin{array}{l}-0.32 \pm 0.27 \\
(-0.88,0.19)\end{array}$ & $\begin{array}{l}-0.05 \pm 0.14 \\
(-0.40,0.18)\end{array}$ & $\begin{array}{l}-0.01 \pm 0.21 \\
(-0.43,0.44)\end{array}$ \\
\hline Cover of grass & $\begin{array}{l}\text { Scale } 4.00 \pm 1.52 \\
\quad(0.00-5.00)\end{array}$ & $\begin{array}{l}0.48 \pm 0.12 \\
(0.24,0.73)\end{array}$ & $\begin{array}{l}0.17 \pm 0.25 \\
(-0.28,0.74)\end{array}$ & $\begin{array}{c}0.06 \pm 0.19 \\
(-0.33,0.43)\end{array}$ & $\begin{array}{l}-0.05 \pm 0.11 \\
(-0.28,0.18)\end{array}$ & $\begin{array}{c}0.22 \pm 0.26 \\
(-0.12,0.89)\end{array}$ \\
\hline Cover of rocks and stones & $\begin{array}{l}\text { Scale } 2.00 \pm 0.97 \\
\quad(0.00-4.00)\end{array}$ & $\begin{array}{l}-0.01 \pm 0.24 \\
(-0.48,0.47)\end{array}$ & $\begin{array}{l}-0.05 \pm 0.35 \\
(-0.80,0.62)\end{array}$ & $\begin{array}{c}0.27 \pm 0.34 \\
(-0.32,1.03)\end{array}$ & $\begin{array}{l}-0.01 \pm 0.15 \\
(-0.33,0.32)\end{array}$ & $\begin{array}{c}0.03 \pm 0.27 \\
(-0.48,0.65)\end{array}$ \\
\hline Cover of human structures & $\begin{array}{c}\text { Scale } 3.50 \pm 1.74 \\
(0.00-5.00)\end{array}$ & $\begin{array}{l}0.69 \pm 0.13 \\
(0.46,0.97)\end{array}$ & $\begin{array}{c}0.31 \pm 0.24 \\
(-0.07,0.88)\end{array}$ & $\begin{array}{l}0.05 \pm 0.21 \\
(-0.31,0.51)\end{array}$ & $\begin{array}{l}-0.07 \pm 0.12 \\
(-0.35,0.12)\end{array}$ & $\begin{array}{c}0.10 \pm 0.19 \\
(-0.26,0.54)\end{array}$ \\
\hline $\begin{array}{l}\text { Transect length } \\
\text { (standardised) }\end{array}$ & $\begin{array}{c}\text { Metres } 175.00 \pm 72.59 \\
(60.00-384.00)\end{array}$ & $\begin{array}{l}-0.01 \pm 0.20 \\
(-0.40,0.41)\end{array}$ & $\begin{array}{l}-0.01 \pm 0.31 \\
(-0.64,0.62)\end{array}$ & $\begin{array}{c}0.33 \pm 0.37 \\
(-0.24,1.18)\end{array}$ & $\begin{array}{c}0.01 \pm 0.16 \\
(-0.31,0.35)\end{array}$ & $\begin{array}{c}0.14 \pm 0.26 \\
(-0.28,0.74)\end{array}$ \\
\hline Elevation (standardised) & $\begin{array}{c}\text { Metres above sea level } \\
194.5 \pm 94.25(10.00 \\
303.00)\end{array}$ & $\begin{array}{l}-0.05 \pm 0.21 \\
(-0.47,0.36)\end{array}$ & $\begin{array}{l}-0.01 \pm 0.32 \\
(-0.65,0.64)\end{array}$ & $\begin{array}{c}-0.69 \pm 0.38 \\
(-1.47 .-0.01)\end{array}$ & $\begin{array}{l}-0.05 \pm 0.17 \\
(-0.48,0.21)\end{array}$ & $\begin{array}{c}0.01 \pm 0.27 \\
(-0.57 .0 .55)\end{array}$ \\
\hline $\begin{array}{l}\text { Overdispersion } \\
\text { parameter } \Theta\end{array}$ & & $\begin{array}{l}0.97 \pm 0.30 \\
(0.54,1.70)\end{array}$ & $\begin{array}{l}0.31 \pm 0.25 \\
(0.12,0.98)\end{array}$ & $\begin{array}{l}3.78 \pm 15.17 \\
(0.19,47.20)\end{array}$ & $\begin{array}{c}23.69 \pm 14.70 \\
(1.11,48.68)\end{array}$ & $\begin{array}{r}24.97 \pm 14.32 \\
(1.66,48.75)\end{array}$ \\
\hline
\end{tabular}

(during the daytime 8:00-11:30) (see Table 2 for a summary of the counts of each species during our surveys). The combination of transect and visual encounter surveys is known to be effective in detecting reptiles in tropical environments (Doan 2003; McDiarmid et al. 2011; Smith et al. 2012a). 
Table 2. Summary of the counts (number of observations per each 10-minute survey) of five species of alien reptiles on Christmas Island across the 34 survey sites (mean \pm standard deviation, and range). Three repeated surveys were conducted during each day and night time conditions in each survey site. The raw data are available at https://figshare.com/s/e85ac13693bc6272437f

\begin{tabular}{lcc}
\hline \multicolumn{1}{c}{ Species } & Day surveys & Night surveys \\
\hline Common house gecko (Hemidactylus frenatus) & $0.74 \pm 1.44(0.00-7.00)$ & $6.51 \pm 7.84(0.00-35.00)$ \\
Stump-toed gecko (Gehyra mutilata) & $0.00 \pm 0.00(0.00-0.00)$ & $0.58 \pm 1.45(0.00-7.00)$ \\
Grass skink (Lygosoma bowringii) & $0.31 \pm 0.84(0.00-5.00)$ & $0.01 \pm 0.10(0.00-1.00)$ \\
Flowerpot snake (Indotyphlops braminus) & $0.08 \pm 0.44(0.00-2.00)$ & $0.11 \pm 0.31(0.00-1.00)$ \\
Wolf snake (Lycodon capucinus) & $0.06 \pm 0.28(0.00-2.00)$ & $0.05 \pm 0.26(0.00-2.00)$ \\
\hline
\end{tabular}

Time-limited transects do not neccesarily require repeated survey occasions (Catenazzi et al. 2016), but our repeated surveys allowed us to estimate both the abundance and the probability of individual detection of alien reptiles via hierarchical models (Royle 2004; Kéry and Royle 2016; Ficetola et al. 2018). Our time-limited approach was a minor modification of the methodology employed by Christmas Island National Park Staff to survey for both native and alien reptiles on the island (Smith et al. 2012a, 2012b). Therefore, our time-limited methodology aligns well with pre-existing protocols, which can be easily adapted to inform the management of alien reptiles. Only wolf snakes, found on the last survey occasion, were captured and relinquished to National Parks Australia as required in the conditions of our permits (see Acknowledgements). All other individuals were either not captured or left in the same place where they were found when handling was necessary for identification purposes.

During each survey occasion, we recorded the number of individuals of each alien reptile species detected, and the temperature $\left({ }^{\circ} \mathrm{C}\right)$ at four different heights in the habitat (Table 1). These four temperatures were used to model the probabilities of detection. For each survey site, we collected information on eight covariates believed to influence the site abundance of alien reptiles; including vegetation cover and geographical features (Table 1). We defined the cover of different microhabitat characteristics in each site following the semiquantitative Braun-Blanquet scale (Sutherland 2006). We gathered information on the altitude (metres above sea level; sourced from the $\mathrm{Na}$ tional Park digital elevation map), and the Euclidean distance from the survey site to the port (metres). The port has been the point of entrance for all the alien reptiles to the island and closer sites might be more likely to have higher abundances (Fritts 1993; Smith et al. 2012b). The four temperature measures, the elevation, the transect length, and the distance to the port were standardised (centred by their mean and scaled by their standard deviation). All the detection data, temperatures and the covariates used in the models are available from https://figshare.com/s/e85ac13693bc6272437f. We assumed that the number of animals counted $\left(N d_{i, z}\right)$ at survey site $i$ during surveying occasion $z$ follows a Binomial distribution with parameters $N_{i}$ and $p_{i, z}$ :

$$
N d_{i, z}-\operatorname{Binominal}\left(N_{i}, p_{i, z}\right)
$$


where $N_{i}$ is the abundance of the species, and $p_{i, z}$ is the probability of individual detection (Kéry and Royle 2016). We modelled the abundance of a species at a survey site, $N_{i}$, as a function of the micro-habitat features, the distance to the port, and the elevation via a Negative Binomial regression. The abundance model was defined as follows:

$$
\begin{gathered}
N_{i} \sim \mathrm{NB}\left(\theta, \frac{\theta}{\left(\theta+\lambda_{i}\right)}\right) \\
\log \left(\lambda_{i}\right)=\sum_{j=1}^{8} \beta_{j} X_{i, j}
\end{gathered}
$$

where $\beta_{j}(j=1, \ldots, 8)$ are the slopes of the model of the mean abundance, $\lambda_{i}$, in survey site $i$ and $X_{i}$ is a vector of the eight covariates used for modelling the mean abundance (Table 1), and $\theta$ is the overdispersion parameter of the Negative Binomial regression. Note that we did not include an intercept in our log-regression (eq. 3) as it is not possible for all micro-habitat variables to equal zero. We modelled the probability of individual detection using a logit model:

$$
\operatorname{logit}\left(p_{i, z}\right)=\alpha_{d}+\sum_{\mathrm{r}=1}^{4} \beta d_{r} T_{i, z, r}
$$

where $\alpha_{d}$ are the time-of-day specific intercepts (day and night), $\beta d_{r}(r=1, \ldots, 4)$ are the slopes of the model of the probability of individual detection, $p_{i, z}$, during survey occasion $z$ at survey site $i$, and $T_{i, z}$ is a vector of the four temperature covariates used for modelling the probability of individual detection (see Table 1). It is important to note that in our model the probability of individual detection is independent of the abundance of the species in the surveyed site (Royle 2004; Kéry and Royle 2016). That is, the probability of individual detection does not vary with abundance (McCarthy et al. 2013; Kéry and Royle 2016). Our modelling approach permits the extrapolation of our probability of individual detection estimates to scenarios with unknown but estimable abundances, typical of novel alien reptile management situations.

We employed Bayesian regularisation to construct robust model structures for the abundance and the probability of individual detection as a function of the covariates (Hooten and Hobbs 2015). Models were constructed and fitted independently for each of the five alien reptile species on Christmas Island. The models were fitted using the NIMBLE package in the $\mathrm{R}$ software environment ( $\mathrm{R}$ Development Core Team 2015; de Valpine et al. 2017). We used relatively uninformative priors for the intercepts in the model, $-N\left(0, \sigma^{2}=10\right)$, and uninformative priors for all the slopes to construct regularised models, $\sim N\left(0, \sigma^{2}\right), \sigma^{2} \sim \operatorname{Exp}(0.5)$. All the models were run using three chains with $1,000,000$ iterations each, and no thinning. After checking for convergence and mixing of the chains, using trace plots and the Gelman-Rubin diagnostic test, we discarded the first 200,000 iterations via a burn-in time, resulting in 2,400,000 draws of the posterior distribution for all the parameters in the models. We used Bayesian $p$-values, based on the Freeman-Tukey goodness-of-fit statistic, residual QQ-plots, and simulations 
to evaluate the fit and identifiability of our abundance-detection models (Dunn and Smyth 1996; Kéry and Royle 2016; Conn et al. 2018; Kéry 2018) (see Supplementary Methods for details). Bayesian $p$-values within the range between 0.05 and 0.95 indicate a model that fits the data adequately (Hobbs and Hooten 2015; Kéry and Royle 2016). The model script is available from https://figshare.com/s/e85ac13693bc6272437f.

\section{Results}

\section{Probabilities of individual detection of alien reptiles on Christmas Island}

Our Bayesian regularised models were an adequate fit to the count data (Bayesian $p$-values close to 0.5 and non-skewed Q-Q plots in all cases; see Supplementary Methods), and revealed that the survey time (day vs night) was the main driver of the probability of individual detection across the five alien reptiles (Table 1; Fig. 2). For three of the five alien reptiles the detection probabilities were higher during
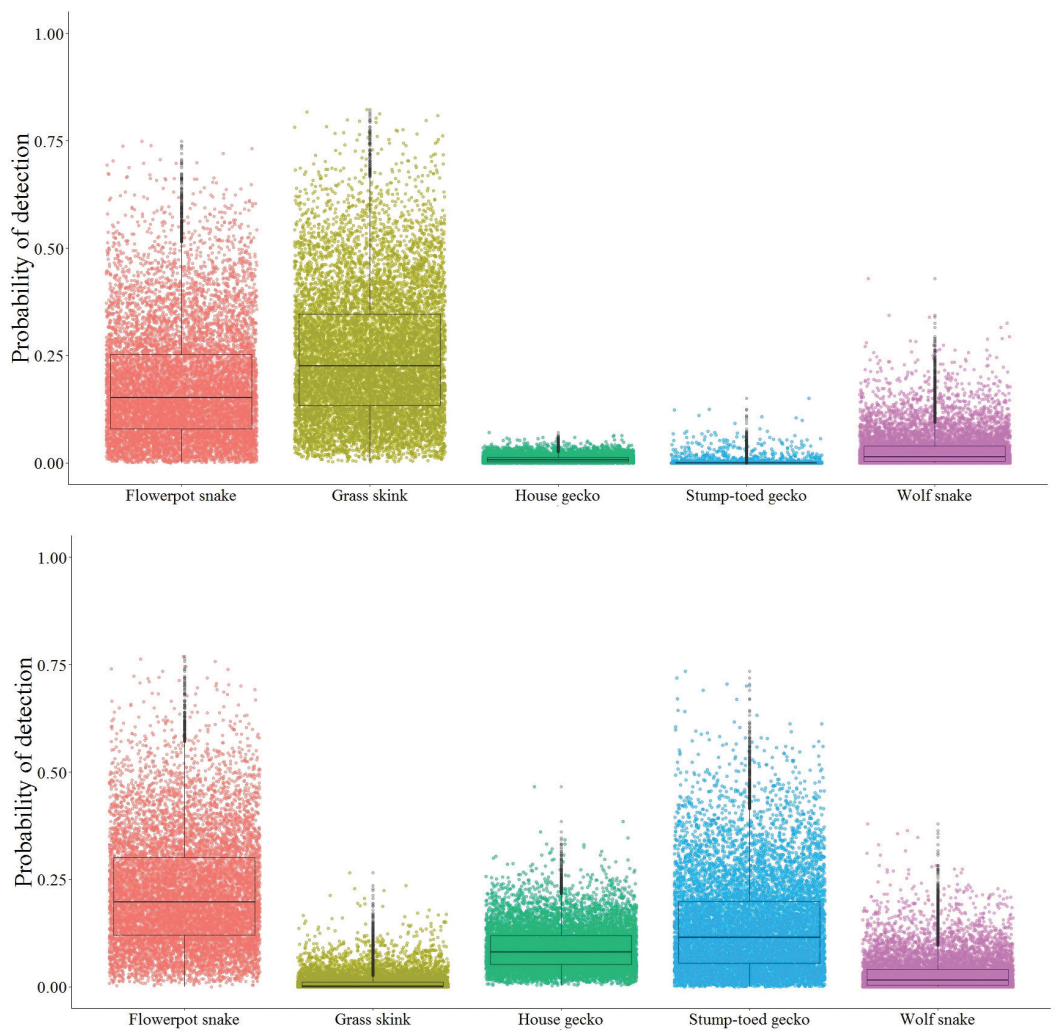

Figure 2. Estimated probabilities of individual detection of five invasive alien reptiles on Christmas Island (Australia) during day time (top panel) and night time surveys (bottom panel). Estimates correspond to the probability of individual detection during a 10-minute survey across the 34 surveying sites. Each dot represents a realisation from 1000 simulations. 


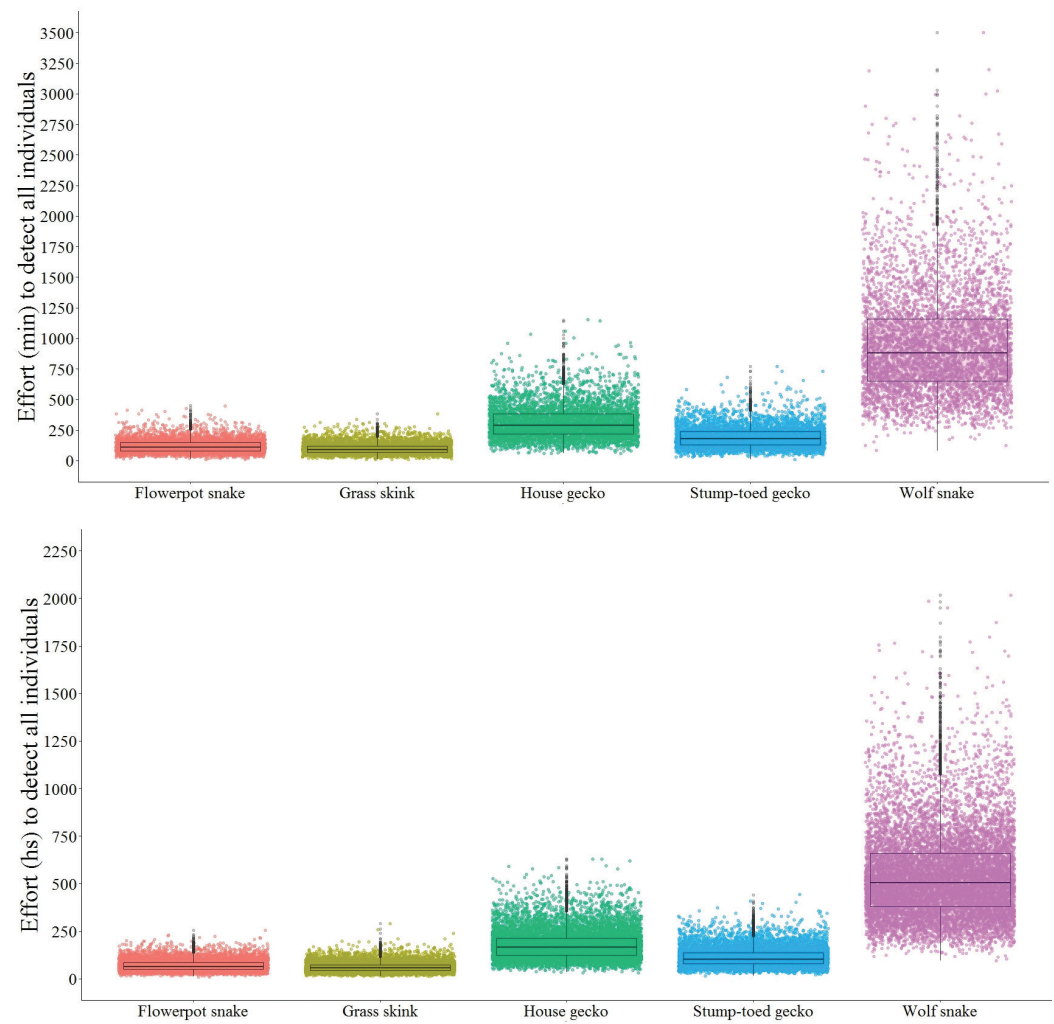

Figure 3. Estimated surveying effort required to detect all 10 individuals of each species of five alien reptiles in two situations and under a best-case detection scenario (i.e., sites surveyed during the time of the day when detection probabilities are higher). Top: surveying effort (minutes) to detect 10 individuals known to be present in one surveying site when only those 10 individuals are present; bottom: surveying effort (hours) to detect 10 individuals distributed at random across 34 surveying sites, where each occupied site harbours one individual, and only ten individuals are present across the 34 surveying sites. We used 10 individuals as an example to showcase and compare detection efforts across different situations. Best-case detection scenarios are night time surveys (common house gecko, stump-toed gecko, and flowerpot snake) and daytime surveys (grass skink and wolf snake). Each dot represents a realisation from 1000 simulations.

night time surveys, whereas only for the grass skink was the detection probability higher during daytime surveys (Table 1; Figs 2, 3). There were virtually no differences between day and night time surveys for the wolf snake. Only in the case of the common house gecko was the probability of individual detection influenced by any of the four covariates included in the models; positively associated with the temperature $120 \mathrm{~cm}$ above ground (mean \pm standard error: $0.52 \pm 0.16 ; 95 \%$ Credible Intervals: [0.22, 0.84]).

All the posterior estimates of the probabilities of individual detection were relatively low, with the upper 95\% Credible Interval estimates of daytime surveys of the grass skink and night time surveys of flowerpot snakes being the only values 
exceeding 0.5 (Table 1). Accordingly, the highest probability of individual detection was for the grass skink during daytime surveys $(0.22 \pm 0.15$; $95 \%$ CIs: $[0.03,0.60])$. The smallest median probability of individual detection was estimated for stump-toed geckos during daytime surveys $(0.001 \pm 0.001 ; 95 \%$ CIs: [0.001, 0.01]).

\section{Abundance of alien reptiles on Christmas Island}

Common house geckos were the most frequently encountered species, followed by stump-toed geckos during night time surveys and grass skinks during daytime surveys (Table 2). Likewise, our posterior estimates of the abundance of the five species showed that the two species of alien geckos were the most abundant species on Christmas Island (Table 1). Wolf snakes were the third most abundant species and flowerpot snakes were the rarest (Table 2).

Our Negative Binomial regressions revealed that common house geckos were more common in sites with higher grass and human structure cover (positive relationships), and that grass skinks tended to become rarer in higher elevation sites (negative relationship with elevation). Across the five alien reptiles, all the covariates had uncertain effects on the estimated alien reptile abundances and probabilities of detection, with wide posterior estimates overlapping zero (Table 1).

\section{Discussion}

The probabilities of detecting individuals using a standardised RBA were consistently low across all the alien reptiles found on Christmas Island. Both the detectability and the abundance of those alien reptiles were difficult to explain given the rather uncertain effects of the covariates tested in our models, even when our surveys explored a representative and variable sample of environmental conditions (Table 1). Only common house geckos were more detectable with increasing temperature $120 \mathrm{~cm}$ above ground, which is concurrent with the species habit of occupying buildings and being found active on the walls of those buildings during our surveys. Low detection probabilities, and the difficulty in predicting both abundance and detection, indicate that managing novel pools of alien reptiles, of yet unknown taxonomic identity, will prove a challenge on both Christmas Island and, by extension, in other places subject to increasing pressure of novel alien reptiles.

It is particularly important to protect island ecosystems, where alien reptiles have produced substantial negative impacts and whose native biodiversity is highly exposed to the threat of alien species (Rodda et al. 1999; Powell 2011; Smith et al. 2012b; Silva-Rocha et al. 2015; Bellard et al. 2017; Moser et al. 2018; van Wilgen et al. 2018). Management activities on islands, excluding targeted eradication post-introduction, will need to be able to detect any potential alien reptiles that arrive on the island, to provide effective protection against these novel alien species (García-Díaz et al. 2017b; 
Scott et al. 2017). However, even well-resourced management programs cannot detect and intercept every single alien individual arriving at a new location (Jarrad et al. 2011; Scott et al. 2017). We found important differences in the probability of individual detection of different species of alien reptiles, which implies that one survey method and surveillance effort cannot fit all. It is of particular concern that the posterior estimates of the probability of individual detection of wolf snakes were very low (mean $<0.02$; Table 1). This is unfortunate, because alien snakes represent, amongst all the alien reptiles, some of the worst threats to native species in the recipient communities, including islands (Dorcas et al. 2012; Kraus 2015; Silva-Rocha et al. 2015). Our posterior estimate of the detection probability of wolf snakes was very similar to that reported for other snakes in places around the world and surveyed using different techniques (Kéry 2002; Christy et al. 2010; Durso et al. 2011; Sewell et al. 2012; Durso and Seigel 2015), suggesting that regardless of the location, species and surveying method, snakes are very difficult to detect in the field. In order to properly address the differences between species, and in anticipation of future changes in pathways and species transported, we recommend that management activities base their surveying efforts on species with the smallest detection probability. This approach will maximise the number of new alien reptiles detected and intercepted, even when accepting that not all individuals can possibly be detected.

The compounded effects of low detection probabilities and uncertain effects of covariates will hinder effective measures to manage the emergence of alien reptiles, a conclusion reinforced by previous species-specific research into the management of invasive brown snakes (Boiga irregularis) in Guam (Christy et al. 2010), invasive Burmese pythons (Python bivittatus) in Florida (Reed et al. 2011), and invasive red-eared slider turtles (Trachemys scripta elegans) in the Iberian peninsula (García-Díaz et al. 2017a). Unfortunately, the detectability of alien reptiles remains a challenge to both management and research activities even when sufficient resources are available, as shown by long-term detectability research conducted in Guam (Rodda et al. 2015). In conclusion, managing alien reptiles already established on islands, and future pools of new invasive alien species, will be costly and with no guarantee of success due to both the low detectability of individuals and the difficulty to predict the likely abundance and detectability of alien reptiles.

Framed in this context of overarching uncertainties and high costs, strong preventive policies should be a priority to address the emergent threat of alien reptiles on islands and elsewhere (Jarrad et al. 2011; Rout et al. 2014; Lodge et al. 2016; Scott et al. 2017). As a first step, public agencies tasked with preventive policies for managing alien species (e.g., environmental protection and primary industries agencies) should implement strict quarantine measures and biosecurity regulations (Meyerson and Reaser 2002; Brenton-Rule et al. 2016; Early et al. 2016). These measures and regulations should be aimed at detecting incoming alien reptiles at quarantine border controls before those individuals can escape containment into the wild (Meyerson and Reaser 2002; Jarrad et al. 2015; Brenton-Rule et al. 2016; Chapple et al. 2016; Scott et al. 2017). Australia and New Zealand have biosecurity arrangements in place, even 
if imperfect, to achieve these two management goals and islands elsewhere could draw lessons from these two countries to implement their own preventive strategies (Jarrad et al. 2011; Brenton-Rule et al. 2016; Chapple et al. 2016; García-Díaz et al. 2017b; Scott et al. 2017).

Preventive management activities should be complemented with early detection surveys aimed at detecting new populations of alien reptiles promptly (Vander-Zanden et al. 2010; Jarrad et al. 2015; Scott et al. 2017). Again, the costs incurred by early detection surveys will be high due to the need for large survey efforts to overcome low probabilities of detection of alien reptiles. A combination of citizen-science surveys, public education programs, and strategic surveys by biosecurity agencies is an avenue worth continuing to invest in to implement effective early detection surveys within environmental budgets, which are heavily constrained by limited funding (Gallo and Waitt 2011; Lawson et al. 2015; Scott et al. 2017). Our results and methodology can be extended by incorporating additional quantitative tools, such as Baye's rule, to estimate the surveying effort needed to confidently declare the absence of new alien reptiles given no individuals are detected (Ramsey et al. 2009; Anderson et al. 2013; García-Díaz et al. 2017a). Additionally, the adequacy-particularly, the rates of false positives and negatives - of novel detection methods, such as environmental trace DNA, should be thoroughly explored; although indirect surveillance techniques do not replace the need for capturing alien individuals implicit to many management actions (Hunter et al. 2015; Guillera-Arroita et al. 2017).

More broadly, biosecurity regulations, strict quarantine, and early detection activities should be considered within the framework of robust anticipatory policymaking (Boston 2016, 2017). Anticipatory policy-making for emerging alien species is to be guided by the philosophies of adaptiveness and the precautionary principle (Conroy and Peterson 2013; Boston 2016, 2017). Adaptiveness will require frequently evaluating the performance of preventive tools and policies, such as risk assessments and quarantine, against indicators of risk reduction, and updating the management actions as necessary (Rout et al. 2014; Lodge et al. 2016). The precautionary principle should be central to policy and decision-making to prevent the establishment and spread of emergent alien vertebrates. This is particularly important given the scant knowledge about the impacts of most new alien reptiles and the low likelihood of succeeding in eradicating established, self-sustaining, alien reptile populations (Kraus 2015; García-Díaz et al. 2017a; van Wilgen et al. 2018).

The implementation of stringent preventive policies and early detection activities might be more straightforward on oceanic islands, where their remoteness commonly requires all goods and commodities to be imported via shipping and air traffic routes arriving in a small number (usually one) of ports and airports, limiting the number of potential pathways of transport and points of entry into the island (Kraus 2009; Helmus et al. 2014; Moser et al. 2018). The situation is different on continents and mainland contexts, where there are multiple pathways of transport and many points of entry (Hulme et al. 2008; Leung et al. 2014; Hulme 2015; Yemshanov et al. 2015; García-Díaz et al. 2017b). Further research could explore how well our findings and 
conclusions transfer to mainland scenarios. Research into the detectability of invasive snakes in Florida suggests that they are similarly difficult to detect in mainland settings (Reed et al. 2011).

We have focussed on alien reptiles on islands in this research, but our conclusions are likely applicable to other groups of emergent alien species globally; such as vertebrates in the pet trade (Hulme 2015; Seebens et al. 2018). Building on the realisation of the cornerstone importance of detectability to manage alien species, future work should investigate the extent to which our findings and recommendations hold for different groups of emergent alien species and under other conditions such as mainland environments. In any case, the lack of research and the abundant uncertainties do not preclude the implementation of good preventive policies to manage alien species, an urgent task considering the lack of preventive and early detection capacities in most countries of the world (Early et al. 2016).

\section{Acknowledgements}

This work would not have been possible without the support provided by the all the staff of the Christmas Island National Park, the Christmas Island Natural Resource Management Board, and the Department of Agriculture and Water Resources (Indian Ocean). This research was conducted under permit number CIN_2015_5 (Christmas Island National Park, Director of National Parks, Australian Government) and a Licence to undertake research activities on regulated crown land. The research was approved by the University of Adelaide Animal Ethics Committee (S2014-155). Andrew Robinson, John Measey, and an anonymous reviewer provided constructive feedback that helped improve this manuscript. PG-D was supported by an IPRS/APA scholarship (DET), an Invasive Animals CRC PhD scholarship, and the IA CRC Student Grant. This work was supported by an ARC Discovery Grant (DP140102319) to JVR and PC and ARC Future Fellowships to PC and JVR (FT0991420, FT130100254).

\section{References}

Anderson DP, Ramsey DSL, Nugent G, Bosson M, Livingstone P, Martin PAJ, Sergeant E, Gormley AM, Warburton B (2013) A novel approach to assess the probability of disease eradication from a wild-animal reservoir host. Epidemiology \& Infection 141: 1509-1521. https://doi.org/10.1017/S095026881200310X

Barker RJ, Schofield MR, Link WA, Sauer JR (2018) On the reliability of N-mixture models for count data. Biometrics 74: 369-377. https://doi.org/10.1111/biom.12734

Bellard C, Rysman J-F, Leroy B, Claud C, Mace GM (2017) A global picture of biological invasion threat on islands. Nature Ecology \& Evolution 1: 1862-1869. https://doi. org/10.1038/s41559-017-0365-6 
Boston J (2016) Anticipatory governance: how well is New Zealand safeguarding the future? Policy Quarterly 12: 11-24. https://doi.org/10.26686/pq.v12i3.4614

Boston J (2017) Safeguarding the Future: Governing in an Uncertain World. Bridget Williams Books, Wellington, 215 pp. https://doi.org/10.7810/9780947518257

Brenton-Rule E, Frankel S, Lester P (2016) Improving management of invasive species: New Zealand's approach to pre-and post-border pests. Policy Quarterly 12: 17-25. https://doi. org/10.26686/pq.v12i1.4582

Capinha C, Seebens H, Cassey P, García-Díaz P, Lenzner B, Mang T, Moser D, Pyšek P, Rödder D, Scalera R, Winter M, Dullinger S, Essl F (2017) Diversity, biogeography and the global flows of alien amphibians and reptiles. Diversity and Distributions 23: 1313-1322. https://doi.org/10.1111/ddi.12617

Catenazzi A, Richards S, Glos J (2016) Herpetofauna. In: Larsen TH (Ed.) Core Standardized Methods for Rapid Biological Field Assessment. Conservation International, Arlington, VA, 110-126.

Chapple DG, Knegtmans J, Kikillus H, van Winkel D (2016) Biosecurity of exotic reptiles and amphibians in New Zealand: building upon Tony Whitaker's legacy. Journal of the Royal Society of New Zealand 46: 66-84. https://doi.org/10.1080/03036758.2015.1108344

Christy MT, Yackel Adams AA, Rodda GH, Savidge JA, Tyrrell CL (2010) Modelling detection probabilities to evaluate management and control tools for an invasive species. Journal of Applied Ecology 47: 106-113. https://doi.org/10.1111/j.1365-2664.2009.01753.x

Claussen J (2005) Native Plants of Christmas Island. Australian Biological Resources Study, CSIRO, Canberra, Australia, 152 pp.

Conn P, Johnson D, Williams P, Melin S, Hooten M (2018) A guide to Bayesian model checking for ecologists. Ecological Applications 88: 526-542. https://doi.org/10.1002/ecm.1314

Conroy MJ, Peterson JT (2013) Decision Making in Natural Resource Management: a Structured, Adaptive Approach. John Wiley \& Sons, West Sussex, 474 pp. https://doi. org/10.1002/9781118506196

de Valpine P, Turek D, Paciorek CJ, Anderson-Bergman C, Lang DT, Bodik R (2017) Programming with models: writing statistical algorithms for general model structures with NIMBLE. Journal of Computational and Graphical Statistics 26: 403-413. https://doi.or $\mathrm{g} / 10.1080 / 10618600.2016 .1172487$

Dorcas ME, Willson JD, Reed RN, Snow RW, Rochford MR, Miller MA, Meshaka WE, Andreadis PT, Mazzotti FJ, Romagosa CM (2012) Severe mammal declines coincide with proliferation of invasive Burmese pythons in Everglades National Park. Proceedings of the National Academy of Sciences 109: 2418-2422. https://doi.org/10.1073/pnas.1115226109

Dunn PK, Smyth GK (1996) Randomized quantile residuals. Journal of Computational and Graphical Statistics 5: 236-244. https://doi.org/10.2307/1390802

Durso AM, Seigel RA (2015) A snake in the hand is worth 10,000 in the bush. Journal of Herpetology 49: 503-506. https://doi.org/10.1670/15-49.04.1

Durso AM, Willson JD, Winne CT (2011) Needles in haystacks: Estimating detection probability and occupancy of rare and cryptic snakes. Biological Conservation 144: 1508-1515. https://doi.org/10.1016/j.biocon.2011.01.020

Early R, Bradley BA, Dukes JS, Lawler JJ, Olden JD, Blumenthal DM, Gonzalez P, Grosholz ED, Ibanez I, Miller LP, Sorte CJB, Tatem AJ (2016) Global threats from invasive alien 
species in the twenty-first century and national response capacities. Nature Communications 7: 12485. https://doi.org/10.1038/ncomms12485

Ficetola GF, Barzaghi B, Melotto A, Muraro M, Lunghi E, Canedoli C, Parrino EL, Nanni V, Silva-Rocha I, Urso A (2018) N-mixture models reliably estimate the abundance of small vertebrates. Scientific Reports 8: 10357. https://doi.org/10.1038/s41598-018-28432-8

Fritts TH (1993) The common wolf snake, Lycodon aulicus capucinus, a recent colonists of Christmas Island in the Indian Ocean. Wildlife Research 20: 261-265. https://doi. org/10.1071/WR9930261

Gallo T, Waitt D (2011) Creating a successful citizen science model to detect and report invasive species. BioScience 61: 459-465. https://doi.org/10.1525/bio.2011.61.6.8

García-Díaz P, Ramsey DSL, Woolnough AP, Franch M, Llorente GA, Montori A, Buenetxea X, Larrinaga AR, Lasceve M, Álvarez A, Traverso JM, Valdeón A, Crespo A, Rada V, Ayllón E, Sancho V, Lacomba JI, Bataller JV, Lizana M (2017a) Challenges in confirming eradication success of invasive red-eared sliders. Biological Invasions 19: 2739-2750. https://doi. org/10.1007/s10530-017-1480-7

García-Díaz P, Ross JV, Woolnough AP, Cassey P (2017b) Managing the risk of wildlife disease introduction: pathway-level biosecurity for preventing the introduction of alien ranaviruses. Journal of Applied Ecology 54: 234-241. https://doi.org/10.1111/1365-2664.12749

Gregory S, Henderson W, Smee E, Cassey P (2014) Eradications of Vertebrate Pests in Australia: a Review and Guidelines for Future Best Practice. Invasive Animals Cooperative Research Centre, Canberra, 76 pp.

Guillera-Arroita G, Lahoz-Monfort JJ, van Rooyen AR, Weeks AR, Tingley R (2017) Dealing with false positive and false negative errors about species occurrence at multiple levels. Methods in Ecology and Evolution 8: 1081-1091. https://doi.org/10.1111/2041-210X.12743

Hartig F (2018) Package "DHARMa”: residual diagnostics for hierarchical (multi-level/mixed) regression models. Package "DHARMa" https://cran.r-project.org/web/packages/DHAR$\mathrm{Ma} /$ vignettes/DHARMa.html

Helmus MR, Mahler DL, Losos JB (2014) Island biogeography of the Anthropocene. Nature 513: 543-546. https://doi.org/10.1038/nature13739

Hobbs NT, Hooten MB (2015) Bayesian Models: a Statistical Primer for Ecologists. Princeton University Press, Princeton, 299 pp. https://doi.org/10.1515/9781400866557

Holden MH, Nyrop JP, Ellner SP (2016) The economic benefit of time-varying surveillance effort for invasive species management. Journal of Applied Ecology 53: 712-721 https:// doi.org/10.1111/1365-2664.12617

Hooten MB, Hobbs NT (2015) A guide to Bayesian model selection for ecologists. Ecological Monographs 85: 3-28. https://doi.org/10.1890/14-0661

Howald G, Donlan C, Galván JP, Russell JC, Parkes J, Samaniego A, Wang Y, Veitch D, Genovesi P, Pascal M (2007) Invasive rodent eradication on islands. Conservation Biology 21: 1258-1268. https://doi.org/10.1111/j.1523-1739.2007.00755.x

Hulme PE (2015) Invasion pathways at a crossroad: policy and research challenges for managing alien species introductions. Journal of Applied Ecology 52: 1418-1424. https://doi. org/10.1111/1365-2664.12470

Hulme PE, Bacher S, Kenis M, Klotz S, Kühn I, Minchin D, Nentwig W, Olenin S, Panov V, Pergl J, Pyšek P, Roques A, Sol D, Solarz W, Vilá M (2008) Grasping at the routes of 
biological invasions: a framework for integrating pathways into policy. Journal of Applied Ecology45: 403-414. https://doi.org/10.1111/j.1365-2664.2007.01442.x

Hunter ME, Oyler-McCance SJ, Dorazio RM, Fike JA, Smith BJ, Hunter CT, Reed RN, Hart KM (2015) Environmental DNA (eDNA) sampling improves occurrence and detection estimates of invasive Burmese pythons. PloS ONE 10: e0121655. https://doi.org/10.1371/ journal.pone.0121655

Jarrad FC, Barrett S, Murray J, Stoklosa R, Whittle P, Mengersen K (2011) Ecological aspects of biosecurity surveillance design for the detection of multiple invasive animal species. Biological Invasions 13: 803-818. https://doi.org/10.1007/s10530-010-9870-0

Jarrad FC, Low-Choy S, Mengersen K (2015) Biosecurity Surveillance: Quantitative Approaches. CABI, Croydon, 386 pp. https://doi.org/10.1079/9781780643595.0000

Kéry M (2002) Inferring the absence of a species: a case study of snakes. Journal of Wildlife Management 66: 330-338. https://doi.org/10.2307/3803165

Kéry M (2018) Identifiability in N-mixture models: a large-scale screening test with bird data. Ecology 99: 281-288. https://doi.org/10.1002/ecy.2093

Kéry M, Royle AJ (2016) Applied Hierarchical Modeling in Ecology. Analysis of Distribution, Abundance and Species Richness in R and BUGS. Academic Press, London, 783 pp. https://doi.org/10.1016/B978-0-12-801378-6.00001-1

Kraus F (2009) Alien Reptiles and Amphibians: A Scientific Compendium and Analysis. Invading Nature: Springer Series in Invasion Ecology. Springer, Dordrecht, 369 pp.

Kraus F (2015) Impacts from invasive reptiles and amphibians. Annual Review of Ecology, Evolution, and Systematics 46: 75-97. https://doi.org/10.1146/annurev-ecolsys-112414-054450

Larsen TH (2016) Core Standardized Methods for Rapid Biological Field Assessment. Conservation International, Arlington, $208 \mathrm{pp}$.

Lawson B, Petrovan SO, Cunningham AA (2015) Citizen science and wildlife disease surveillance. EcoHealth 12: 693-702. https://doi.org/10.1007/s10393-015-1054-z

Leung B, Springborn MR, Turner JA, Brockerhoff EG (2014) Pathway-level risk analysis: the net present value of an invasive species policy in the US. Frontiers in Ecology and the Environment 12: 273-279. https://doi.org/10.1890/130311

Lodge DM, Simonin PW, Burgiel SW, Keller RP, Bossenbroek JM, Jerde CL, Kramer AM, Rutherford ES, Barnes MA, Wittmann ME, Chadderton WL, Apriesnig JL, Beletsky D, Cooke RM, Drake JM, Egan SP, Finnoff DC, Gantz CA, Grey EK, Hoff MH, Howeth JG, Jensen RA, Larson ER, Mandrak NE, Mason DM, Martinez FA, Newcomb TJ, Rothlisberger JD, Tucker AJ, Warziniack TW, Zhang H (2016) Risk analysis and bioeconomics of invasive species to inform policy and management. Annual Review of Environment and Resources 41: 453-488. https://doi.org/10.1146/annurev-environ-110615-085532

McCarthy MA, Moore JL, Morris WK, Parris KM, Garrard GE, Vesk PA, Rumpff L, Giljohann KM, Camac JS, Bau SS, Friend T, Harrison B, Yue B (2013) The influence of abundance on detectability. Oikos 122: 717-726. https://doi.org/10.1111/j.1600-0706.2012.20781.x

McIntosh CR, Finnoff DC, Settle C, Shogren JF (2009) Economic valuation and invasive species. In: Keller RP, Lodge DM, Lewis MA, Shogren JF (Eds) Bioeconomics Invasive Species: Integrating Ecology, Economics, Policy, and Management. Oxford University Press, New York, 151-179. 
Meyerson LA, Reaser JK (2002) Biosecurity: moving toward a comprehensive approach. BioScience 52: 593-600.

Morris TP, White IR, Crowther JR (2017) Using simulation studies to evaluate statistical methods. ArXiv Prepr. ArXiv171203198.

Moser D, Lenzner B, Weigelt P, Dawson W, Kreft H, Pergl J, Pyšek P, van Kleunen M, Winter M, Capinha C, Cassey P, Dullinger S, Economo EP, García-Díaz P, Guénard B, Hofhansl F, Mang T, Seebens H, Essl F (2018) Remoteness promotes biological invasions on islands worldwide. Proceedings of the National Academy of Sciences 115: 9270-9275. https:// doi.org/10.1073/pnas.1804179115

Powell R (2011) Conservation of the herpetofauna on the Dutch Windward Islands: St. Eustatius, Saba, and St. Maarten. In: Hailey A, Wilson BS, Horrocks JA (Eds) Conservation of Caribbean Island Herpetofaunas, Vol. 2: Regional Accounts of the West Indies. Brill, Leiden, The Netherlands, 189-204. https://doi.org/10.1163/ej.9789004194083.i-439.76

R Development Core Team (2015) R: A Language and Environment for Statistical Computing. R Foundation for Statistical Computing, Vienna, Austria.

Ramsey DS, Parkes J, Morrison SA (2009) Quantifying eradication success: the removal of feral pigs from Santa Cruz Island, California. Conservation Biology 23: 449-459. https://doi. org/10.1111/j.1523-1739.2008.01119.x

Reed RN, Hart KM, Rodda GH, Mazzotti FJ, Snow RW, Cherkiss M, Rozar R, Goetz S (2011) A field test of attractant traps for invasive Burmese pythons (Python molurus bivittatus) in southern Florida. Wildlife Research 38: 114-121. https://doi.org/10.1071/WR10202

Rodda GH, Dean-Bradley K, Campbell EW, Fritts TH, Lardner B, Adams AAY, Reed RN (2015) Stability of detectability over 17 years at a single site and other lizard detection comparisons from Guam. Journal of Herpetology 49: 513-521. https://doi.org/10.1670/14-085

Rodda GH, Sawai Y, Chiszar D, Tanaka H (1999) Problem Snake Management: The Habu and the Brown Treesnake. Comstock Publishing Associates, Ithaca, 534 pp.

Rout TM, Moore JL, McCarthy MA (2014) Prevent, search or destroy? A partially observable model for invasive species management. Journal of Applied Ecology 51: 804-813. https:// doi.org/10.1111/1365-2664.12234

Royle JA (2004) N-mixture models for estimating population size from spatially replicated counts. Biometrics 60: 108-115. https://doi.org/10.1111/j.0006-341X.2004.00142.x

Scott JK, McKirdy SJ, van der Merwe J, Green R, Burbidge AA, Pickles G, Hardie DC, Morris K, Kendrick PG, Thomas ML, Horton KL, O’Connor SM, Downs J, Stoklosa R, Lagdon R, Marks B, Nairn M, Mengersen K (2017) Zero-tolerance biosecurity protects high-conservation-value island nature reserve. Scientific Reports 7: 772. https://doi.org/10.1038/s41598-017-00450-y

Seebens H, Blackburn TM, Dyer EE, Genovesi P, Hulme PE, Jeschke JM, Pagad S, Pyšek P, van Kleunen M, Winter M, Ansong M, Arianoutsou M, Bacher S, Blasius B, Brockerhoff EG, Brundu G, Capinha C, Causton CE, Celesti-Grapow L, Dawson W, Dullinger S, Economo EP, Fuentes N, Guénard B, Jäger H, Kartesz J, Kenis M, Kühn I, Lenzner B, Liebhold AM, Mosena A, Moser D, Nentwig W, Nishino M, Pearman D, Pergl J, Rabitsch W, RojasSandoval J, Roques A, Rorke S, Rossinelli S, Roy HE, Scalera R, Schindler S, Štajerová K, Tokarska-Guzik B, Walker K, Ward DF, Yamanaka T, Essl F (2018) Global rise in emerging alien species results from increased accessibility of new source pools. Proceedings of the National Academy of Sciences 115: 2264-2273. https://doi.org/10.1073/pnas.1719429115 
Sewell D, Guillera-Arroita G, Griffiths RA, Beebee TJC (2012) When is a species declining? Optimizing survey effort to detect population changes in reptiles. PloS ONE 7: e43387. https://doi.org/10.1371/journal.pone.0043387

Silva-Rocha I, Salvi D, Sillero N, Mateo JA, Carretero MA (2015) Snakes on the Balearic Islands: an invasion tale with implications for native biodiversity conservation. PloS ONE 10: e0121026. https://doi.org/10.1371/journal.pone.0121026

Smith MJ, Boland CR, Maple D, Tiernan B (2012a) The Christmas Island blue-tailed skink (Cryptoblepharus egeriae): a survey protocol and an assessment of factors that relate to occupancy and detection. Records of the Western Australia Museum 427: 40-44. https://doi. org/10.18195/issn.0312-3162.27(1).2012.040-044

Smith MJ, Cogger H, Tiernan B, Maple D, Boland C, Napier F, Detto T, Smith P (2012b) An oceanic island reptile community under threat: The decline of reptiles on Christmas Island, Indian Ocean. Herpetological Conservation and Biology 7: 206-218.

Sutherland WJ (2006) Ecological Census Techniques: A Handbook. Cambridge University Press, Cambridge, 446 pp. https://doi.org/10.1017/CBO9780511790508

Vander-Zanden MJ, Hansen GJ, Higgins SN, Kornis MS (2010) A pound of prevention, plus a pound of cure: early detection and eradication of invasive species in the Laurentian Great Lakes. Journal of Great Lakes Research 36: 199-205. https://doi.org/10.1016/j.jglr.2009.11.002

van Wilgen NJ, Gillespie MS, Richardson DM, Measey J (2018) A taxonomically and geographically constrained information base limits non-native reptile and amphibian risk assessment: a systematic review. PeerJ 6: e5850. https://doi.org/10.7717/peerj.5850

Wyatt KB, Campos PF, Gilbert MTP, Kolokotronis S-O, Hynes WH, DeSalle R, Daszak P, MacPhee RD, Greenwood AD (2008) Historical mammal extinction on Christmas Island (Indian Ocean) correlates with introduced infectious disease. PloS ONE 3: e3602. https:// doi.org/10.1371/journal.pone.0003602

Yemshanov D, Koch FH, Ducey M, Venette RC (2015) Making Invasion models useful for decision makers; incorporating uncertainty, knowledge gaps, and decision-making preferences. In: Venette RC (Ed.) Pest Risk Modeling and Mapping for Invasive Alien Species. CABI, Wallingford, 206-222. https://doi.org/10.1079/9781780643946.0206

\section{Supplementary material I}

\section{Model evaluation and estimability}

Authors: Pablo García-Díaz, Joshua V. Ross, Miquel Vall-llosera, Phillip Cassey

Data type: measurement

Copyright notice: This dataset is made available under the Open Database License (http://opendatacommons.org/licenses/odbl/1.0/). The Open Database License $(\mathrm{ODbL})$ is a license agreement intended to allow users to freely share, modify, and use this Dataset while maintaining this same freedom for others, provided that the original source and author(s) are credited.

Link: https://doi.org/10.3897/neobiota.45.31009.suppl1 